
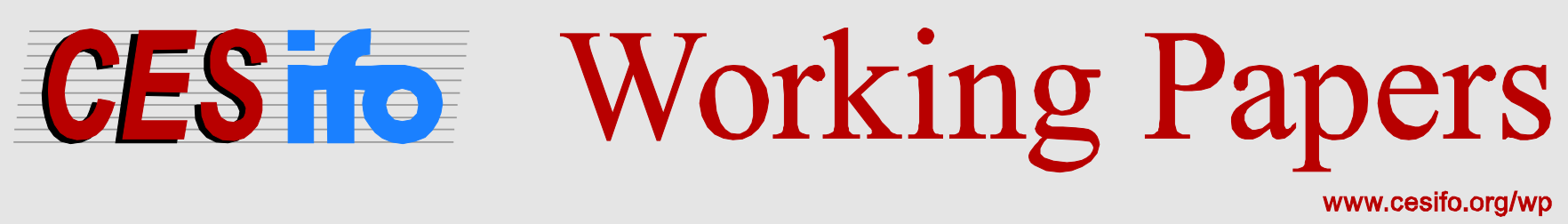

\title{
Much Ado about Nothing? The Role of Primary School Catchment Areas for Ethnic School Segregation. Evidence from a Policy Reform
}

\author{
Anna Makles \\ Kerstin Schneider
}

CESIFO WORKING PAPER NO. 4520

CATEGORY 5: ECONOMICS OF EDUCATION

DECEMBER 2013

An electronic version of the paper may be downloaded

- from the SSRN website:

- from the RePEc website:

- from the CESifo website: WWW.SSRN.com

www.RePEc.org

www.CESifo-group.org/wp

\section{CESifo}




\title{
Much Ado about Nothing? The Role of Primary School Catchment Areas for Ethnic School Segregation. Evidence from a Policy Reform
}

\begin{abstract}
By the 2008/09 school year the federal state of North Rhine-Westphalia (Germany) abolished binding school catchment areas (SCAs) in all municipalities. The reform has been controversial and it was feared that school choice would increase ethnic segregation. Using data on all primary schools, we contribute to this debate by analyzing ethnic segregation before and after the reform. We discuss drawbacks of commonly used segregation indices and their interpretation as well as causality issues. Although there is an increase in segregation over the time period studied, our results show that segregation has not been affected by the policy reform.
\end{abstract}

JEL-Code: I280, J150, H750.

Keywords: school catchment areas, ethnic segregation, school choice, policy reform.

\author{
Anna Makles \\ Schumpeter School of Business and \\ Economics \\ University of Wuppertal \\ Gaussstr. 20 \\ Germany - 42119 Wuppertal \\ makles@wiwi.uni-wuppertal.de
}

\author{
Kerstin Schneider \\ Schumpeter School of Business and \\ Economics \\ University of Wuppertal \\ Gaussstr. 20 \\ Germany - 42119 Wuppertal \\ schneider@wiwi.uni-wuppertal.de
}




\section{Introduction}

During the last decade, several changes to the German educational system were discussed and put into practice. While their main goal is to improve the academic performance of students, social and ethnic disparity is still an acknowledged and unsolved weakness of the German school system. A child's socio-economic background is a better predictor of educational achievement in Germany than in many other countries. Hence, another objective of educational policy in Germany is to assist disadvantaged groups in obtaining better education and to guarantee equal learning opportunities.

To this end, a possible trade-off between performance and equity is often discussed (Wößmann, 2008). In particular, when issues of school choice are on the agenda, there is no easy answer. Choice is thought to have a positive impact on competition between schools and might therefore increase the quality of schooling (Hoxby, 2003; Figlio and Hart, 2010; Hanushek, Kain, and Rivkin, 2009; Hastings and Weinstein, 2008; Fryer and Levitt, 2004). However, the results of many studies suggest that increased school choice also has potentially negative effects (Lankfort and Wyckoff, 2001; Bifulco, Ladd, and Ross, 2009). School choice tends to increase social and ethnic segregation rather than to decrease it (Burgess and Briggs, 2006). In addition, if advantaged families tend to practice school choice more often than disadvantaged families, ethnic and social segregation may result in segregation by ability (Hanushek, Kain, and Rivkin, 2009; Allen, 2007). As a consequence of school choice, negative peer effects and the gap in achievement between advantaged and disadvantaged students may further increase.

This paper contributes to the school choice and segregation debate by analyzing the effect of a far reaching school reform on segregation: the abolition of primary school catchment areas (SCAs) in North Rhine-Westphalia (NRW), the most populous German federal state. In 2006, the state government passed a law abolishing all binding SCAs in the 396 municipalities by the 2008/09 school year. Hence, parents in NRW - unlike their counterparts in other German federal states - have been allowed to choose a primary school independent of their place of residence. The intention of this new regulation was to increase parental school choice and to foster competition between schools. However, the most frequently-cited argument by politicians against free school choice is the fear of increased segregation and educational disparity. 
Only few studies address the effect of changes in educational policy on choice and especially its effect on segregation. In one such study, Söderström and Uusitalo (2010) analyze the change in the admission system of public upper secondary schools in Stockholm. Before 2000, proximity to school was the main criterion for being admitted to any given school. Since 2000, admission has been based on student ability only. Söderström and Uusitalo's results indicate that school segregation based on family background as well as ethnicity have increased significantly since 2000. However, the study does not determine whether increased segregation is caused by parental choice or by the admittance strategy of schools or both. Altrichter et al. (2011) analyze the effect of the abolishment of primary school catchment areas in the city of Linz (Austria). They report increased segregation by ethnicity and family income in the first years after the policy reform, but they cannot attribute the change causally to the absence of catchment areas.

Until recently, school choice and its impact on ethnic school segregation has not been a prominent issue in educational policy and research in Germany. It is commonly thought that (a) school segregation is determined by the social structure within the residential districts, i.e. school segregation only mirrors residential segregation, and (b) that there is no school choice at the primary school level which potentially may affect or increase ethnic school segregation. Thus, the focus of research is more on choice in secondary schooling (Dustmann, 2004). It is a little-known fact that even before SCAs were abolished, it was not uncommon to opt out of one's assigned primary school in NRW (Kristen, 2005; Riedel et al., 2010; Schneider et al., 2012) and that school choice did, in fact, already affect the composition of students in primary schools. For the city of Wuppertal and the city of Solingen there is evidence that abolishing SCAs affects choice behavior of the German as well as the non-German population (Riedel et al., 2010; Schneider et al., 2012). Moreover, the observed ethnic composition of students in the first grade is different from the hypothetical composition that arises if every child attended his or her assigned primary school. Thus, the fear of increased ethnic segregation due to more school choice and the resulting educational disparity cannot be disregarded.

To our knowledge, there is no general empirical evidence on the relationship between school choice, SCAs and primary school segregation in Germany. This paper attempts to fill this gap and analyzes the level of ethnic school segregation for all municipalities in NRW five years before and three years after the abolishment of SCAs. 
Unlike the studies by Kristen (2005), Riedel et al. (2010), and Schneider et al. (2012) we do not use data at the individual level and for one municipality only to study the determinants of choice; instead, we use administrative data, which are the statistics on schools for all 396 municipalities in NRW. This allows for more general conclusions. Our focus is on children of immigrant families who are known to be disadvantaged in the German educational system. In particular, we analyze segregation of Turkish and German students and Muslim and non-Muslim students in the first grade of primary school. Our results show that observed as well as systematic ethnic segregation in primary schools were at a high level even before abolishing SCAs. This is in line with earlier literature. However, there is strong evidence that abolishing SCAs has not increased systematic segregation in North Rhine-Westphalia. Moreover, changes in systematic segregation can be explained by characteristics of the municipalities.

The remainder of the paper is organized as follows: In Section 2 we briefly discuss the institutional details of primary school admission in NRW before and after the 2008/09 school year. The data used to analyze ethnic school segregation are described in Section 3, and in Section 4 we explain our empirical strategy. The results are presented in Section 5, and Section 6 concludes the paper.

\section{Primary school admission in NRW: institutional background}

Before the 2008/09 school year, admission to primary school in North RhineWestphalia (NRW), the most populous German federal state, was based on $\S 39(1)$ SchulG NRW [NRW School Law]. School-age ${ }^{1}$ children were assigned to the public primary school (Gemeinschaftsgrundschule) in which catchment area they have lived. Consequently, choice appears to have been rather limited. However, § 39(1) SchulG NRW was not really a strict regulation. First, parents could apply for permission to attend a different school than the one assigned (§ 39(3) SchulG NRW). Second, there are public denominational primary schools (öffentliche Bekenntnisschulen) in NRW. In the following, we simply label them public (primary) schools and denominational (primary) schools. Children in NRW have the right to attend a public denominational school in their municipality or a neighboring municipality if the child has this denomination (§26 SchulG NRW) or if parents wish their child to be educated according to that denomination. In addition to the public and denominational schools,

1 School-age children are generally six years old. 
there is a small number of private primary schools in NRW, which will be disregarded in this study. ${ }^{2}$

As the school catchment areas (SCAs) for primary schools were abolished in 2008/09, parents are theoretically given free choice of school; in practice, however, this is not necessarily the case. First, the amount of information given to parents is still limited and indicators of school quality like student achievement are not published. Second, the schools are (still) given fairly strict legal guidelines on how to determine admission, with distance to the chosen school being still the most important restriction. Hence, at first sight, choice appears to be rather limited even after the reform. But, due to the demographic change, the number of school-age children is decreasing in NRW, leaving more room for choice and for increased competition between schools on the one hand and for more segregation on the other hand. As a consequence, the new state government, which was elected in 2010, immediately changed the school law and reestablished primary school catchment areas. As of the school year 2011/12, it is up to each municipality to reintroduce SCAs.

\section{The data and the definition of ethnic groups}

The administrative data used are from the school statistics of NRW for school years 2006/07 to 2010/11 and include all primary schools. ${ }^{3}$ The data provide school level information on the ethnic composition of each grade by nationality and denomination. Table 1 summarizes the data.

Since the abolishment of SCAs primarily affects first graders, we only use information on first grade classes and use the information on the $2^{\text {nd }}, 3^{\text {rd }}$, and $4^{\text {th }}$ grade of the 2006/07 school year as proxies for the $1^{\text {st }}$ grade in 2003/04, 2004/05, and 2005/06, respectively. Hence, we have a panel of all primary schools in the 396 NRW municipalities for 8 years.

In 2003/04, NRW had 3,415 primary schools with a first grade, almost all of which are public and denominational schools $(3,389$ of 3,415). The number of schools decreases steadily to 3,144 (public and denominational schools: 3,098) in 2010/11, because some schools were closed or merged due to the decreasing number of school-

\footnotetext{
2 In 2003/04 only 26 of a total of 3,415 schools in 396 municipalities were private primary schools (cf. Table 1).

3 The data are provided by IT.NRW (Information und Technik Nordrhein-Westfalen) [State Office for Statistics, North Rhine-Westphalia].
} 
age children. The denominational schools in NRW are important with respect to school choice, as they offer parents choice options even in the presence of SCAs. Hence, we can expect segregation before 2008/09 to be higher in municipalities with both school types, which applies to about $57 \%$ of all municipalities. 74 (of 396) municipalities have denominational schools only, and 95 municipalities have no denominational schools.

As this paper focuses on ethnic segregation before and after abolishing SCAs in NRW, we need to define the ethnic minority group(s) for which segregation is to be analyzed. The administrative records yield information for each primary school on the grade composition by citizenship, which can be used as an indicator for ethnicity. However, after the modification of the German nationality law (StAG), children with non-German parents born in Germany after January $1^{\text {st }}$, 2000 automatically become German citizens if at least one parent has been living in Germany for at least 8 years and has the right to reside permanently in Germany (§ 4(3) StAG). This amendment has led to a decrease in the non-German school-age population, which might well affect indicators of ethnic segregation. In addition, there has been a continuing downward trend in the number of births for both groups since 2001. The number of $1^{\text {st }}$ grade students decreases from 174,310 in 2006/07 to 153,101 in 2010/11 (Table 1); likewise, the number and proportion of non-German students is steadily shrinking, from $13.6 \%$ in 2006/07 to $10.9 \%$ in 2010/11. The proportion of Turkish students decreases from $6.6 \%$ in $2006 / 07$ to $4.1 \%$ in $2010 / 11$.

Since the amendment of the nationality law, nationality is no longer a reliable indicator of a person's ethnic background; nonetheless, the rising number of naturalizations indicates enforced integration of immigrants, who have been residents for many years. Thus, the new law might have changed the composition of the minority groups. This applies in particular to the large group of Turkish students in Germany. ${ }^{4}$ Children of Turkish families who have been living in Germany for a long time and might be better integrated are now granted the German citizenship. ${ }^{5}$ Hence, the group of

170,000 children younger than 10 years of age have a Turkish background (Statistisches Bundesamt, 2010).

5 In 2008, the number of Turkish people living in Germany was about 1.7 million. This amounts to 24 percent of all immigrants in Germany. The average duration of stay of non-German citizens is 18.8 years and 23 years for Turkish citizens. Extending the group to all individuals with a migrant background, the average duration of stay is 20.7 years and 25.6 years for the population of Turkish descent. In NRW, one of the federal states with the largest Turkish population, the corresponding number of Turkish citizens is about 550,000, which means that 29 percent of the immigrants in NRW are Turkish citizens. The number of individuals of Turkish descent is 843,000. Thus 35 percent of the ethnic Turkish population are German citizens (Statistisches Bundesamt, 2010). 
Turkish students after 2006 and 2007 might not only be smaller; the Turkish students might also be less integrated than the group of Turkish students before 2006 and they are likely to be from families with a lower socio-economic status. Thus, we expect segregation between Turkish and German students to increase, because the two groups became more distinct after 2006.

Since the information on the child's ethnicity is not available in the administrative data, we use an additional proxy variable to distinguish ethnic groups. One possible variable that can serve as a proxy for ethnic minorities is denomination. As the largest non-German groups in NRW are from Turkey, Morocco and the Middle East, we use the denomination Muslim as a proxy for ethnicity, as the vast majority of this group is Muslim. ${ }^{6}$ While the number of non-German and Turkish students, as well as the proportion of the Turkish, is decreasing over time, the number of Muslim students remains constant, and the percentage of Muslim students is even increasing (from $12.7 \%$ in $2003 / 04$ to $15.8 \%$ in $2010 / 11$, cf. Table 1 ). As some authors have pointed out (e.g. O’Shaughnessy, 2007; Schneider et al., 2012), parents belonging to minority groups (like Muslims) exhibit school choice less often. Hence, an increasing proportion of Muslim students might reduce the overall likelihood of exercising school choice, thereby increasing segregation in primary schools. In our analysis we will therefore focus on segregation between Turkish and German students as well as segregation between Muslim and non-Muslim students.

Besides the abolition of school catchment areas and the change in the nationality law, there is another policy change that has to be accounted for in the analysis of grade composition and issues of segregation. Until the 2006/07 school year, the cutoff date for enrollment was June $30^{\text {th }}$. Children born between July $1^{\text {st }}$, 1999 and June $30^{\text {th }}$, 2000 are required to enroll in 2006/07. Starting in 2007/08, however, there has been a gradual shifting of the cutoff date for enrollment, with the target cutoff date of September $30^{\text {th }}$ in 2012/13. The variation in cohort size is relevant for our analysis of segregation, because in 2007/08 and 2009/10 a cohort of thirteen months instead of twelve months enters

6 The percentage of Muslims in Turkey is, according to official statistics, 99 percent. About 98 percent of the population in Morocco, Iraq, and Iran are Muslims. The estimated number of Muslims in Germany is between 3.8 and 4.3 million, which amounts to between 4.6 and 5.2 percent of the population. The vast majority of the Muslims in Germany are ethnic Turks (between 2.5 and 2.7 million) and the other Muslims are from Southeastern Europe, the Middle East and North Africa (predominantly Morocco). The percentage of Muslim Turkish families in Germany is unknown. Survey data suggest that 81.4 percent of the ethnic Turkish population in Germany is Muslim. The number of native German Muslims is (roughly) estimated to be between 13,000 and 100,000 (Federal Office for Migration and Refugees, 2009). 
school (Table 1). Since it cannot be assumed that the additional children are distributed randomly within the municipality, we expect these extra children not to be randomly allocated to the schools. Hence, segregation is likely to be affected by increased competition between students for admission to better schools. Finally, since 15 of the 396 municipalities already abolished their catchment areas in 2007/08, there are two types of municipalities to be analyzed. The majority of municipalities (381) abolished SCAs in 2008/09; hence, for these municipalities the analysis of segregation covers five years before and three years after the abolition of SCAs.

To summarize, changes in the nationality law, the new cutoff date and the general demographic change might affect segregation, regardless of the abolition of assignment areas. When changes in segregation are analyzed over a period of time during which various policy adjustments have taken place, the challenge is to decompose the overall change in segregation. Clearly, this decomposition is not straightforward and offers some pitfalls. In our empirical strategy we therefore discuss these issues in more detail and suggest a method to evaluate the effect of the abolition of SCAs.

\section{Empirical strategy}

In our empirical analysis, we use the municipalities as our units of observation for two reasons. First, in NRW, the municipalities are the school authorities and decide on whether to abolish SCAs in 2007/08 or one year later. The municipalities also decide on the location and the potential closure of schools. Second, students' choices are restricted by the distance to school. This is particularly true for $1^{\text {st }}$ graders. Hence, school choice is predominantly practiced within a municipality.

To measure primary school segregation within each municipality, our starting point is the dissimilarity index $D$ (Duncan and Duncan, 1955), the most widely-used measure of dissimilarity and segregation. The formula for this index is given by

$$
D_{m t}=\frac{1}{2} \sum_{j \in J_{m}}\left|\frac{n_{m j 1 t}}{n_{m 1 t}}-\frac{n_{m j 0 t}}{n_{m 0 t}}\right| .
$$

$D_{m t}$ is bounded by 0 and 1 , and it corresponds to the share of students who have to change schools in school year $t$ within municipality $m$ to achieve an equal distribution. The primary schools in each municipality $(m=1, \ldots, M)$ are denoted by $j=1, \ldots, J_{m}$. 
Furthermore, we distinguish between two types of students: minority and non-minority students. The first type has the minority status $g=1$, while the second type has the nonminority status $g=0$. Hence, the number of students of type $g$ in municipality $m$ and primary school $j$ at time $t$ is given by $n_{m j g t}$, and the total number of students in municipality $m$ and primary school $j$ at time $t$ is $n_{m j t}=n_{m j 1 t}+n_{m j 0 t}$.

\subsection{The effect of school choice on segregation}

Despite the popularity of the dissimilarity index and related measures in empirical work, the indices nonetheless suffer from some shortcomings. First, as observed dissimilarity compares the distribution of minority and non-minority students within a municipality, we have to keep in mind that the value of $D_{m t}$ captures residential segregation and segregation caused by school choice. Thus, segregation caused by school choice only is the difference between observed school segregation $D_{m t}$ and unobserved residential segregation. To decompose the level of segregation $D_{m t}$ into a residential and a choice part, information on residential segregation is required. For example, if student addresses and the address of the assigned or nearest primary school were available, hypothetical school segregation, $\tilde{D}_{m t}$, where every child is assumed to visit the nearest or assigned school could be calculated. The difference between $D_{m t}$, the index of observed primary school segregation, and $\tilde{D}_{m t}$ shows the level of primary school segregation caused by school choice only: $D_{m t}^{c}$. Unfortunately, the administrative data do not yield individual information on students' addresses; hence we cannot determine the level of residential segregation, and the part of observed segregation resulting from choice remains unclear. However, since we are not primarily interested in the levels of segregation but in changes of segregation, this is not problematic for the following reason. Since we consider a fairly short time period after the reform, it is plausible to assume that abolishing binding SCAs does not induce relocations of families within a municipality or between municipalities. ${ }^{7}$ Thus residential segregation can be assumed to be fairly constant within a period of three years after abolishing SCAs. Changes in observed segregation are therefore not due to changes in residential segregation but must be explained by other factors.

After the abolition of SCAs there is no need to move/relocate within a municipality or between municipalities to visit a school other than the nearest or assigned one. 
Second, ideally one likes to have a treatment and a control group to claim causal effects. In our context, this requires a study design in which some municipalities or federal states did abolish SCAs and others did not. NRW is, in fact, the only federal state without binding catchment areas between 2008/09 and 2010/11. And NRW is different from other German states in many respects. For instance, it is the only state with denominational schools in addition to public schools, which makes it hard to compare the effects of schools choice to the situation in other states. Moreover, NRW is the most populous and most densely populated federal state with a particularly large immigrant population. A comparison to other federal states with respect to the ethnic composition of the student body is impossible. In consequence our analysis is restricted to NRW, as it is not possible to construct a valid control group from the data of other federal states. Hence in in the following we use data from municipalities in NRW before and after the abolishment of SCAs. We are aware of the shortcomings of the empirical strategy and therefore do not claim causality. However, we carefully separate the effect of abolishing SCAs from other effects by decomposing segregation and applying a suitable estimation strategy to explain segregation.

\subsection{Decomposition of segregation}

As known from the literature on segregation (Carrington and Troske, 1997; Cortese, Falk, and Cohen, 1976), the most common indices of segregation indicate substantial segregation even if the population is randomly allocated across units. As segregation indices are particularly sensitive when group sizes and minority proportions are small, we need to account for changes in group size. As argued earlier, in this study we have to deal with substantial changes in group size that mainly result from the modification of the nationality law, the changed cutoff date for enrollment, and demographic changes.

There are several approaches to account for small samples and small minority shares (Cortese, Falk, and Cohen, 1976; Carrington and Troske, 1997; Allen, Burgess, and Windmeijer, 2009; Rathelot, 2011). In our study, we focus on the correction introduced by Carrington and Troske in 1997, which has been applied in earlier empirical work (Dustmann, Glitz, and Schönberg, 2009; Söderström and Uusitalo, 2010; Aslund and Skans, 2009).

In the analysis we randomly allocate students to a school in their municipality, holding grade size, total number of students, and overall minority proportion in each 
municipality constant. This approach explicitly accounts for the situation in NRW, where primary schools are essentially not allowed to grow, since the number of classes per grade is fixed and the number of students per class is restricted to a maximum of $30 .{ }^{8}$ In addition, restricting the random allocation of students to the municipality level takes the limited mobility of first graders into account.

The Carrington and Troske (1997) approach allows us to obtain an estimate of segregation resulting from a purely random enrollment process across schools within a municipality, which is labeled 'expected segregation' and is denoted by $D_{m t}^{*}$. Hence the idea is to decompose observed segregation in a component that only depends on the minority share and the size of the groups, and a component that captures systematic segregation, i.e. (constant) residential segregation and segregation caused by school choice. Note that expected segregation $\left(D_{m t}^{*}\right)$ is affected whenever the composition of the population in the municipality changes. During the time period of our study the new nationality law was enacted, the new cutoff dates for enrollment were established, and finally the demographic change affected the proportion of minorities in the municipality and the population of first graders. Since all of these changes affect group sizes, they also affect expected segregation. With respect to the existence of SCAs, however, expected segregation is constant, as neither the group size nor the proportion of minorities change.

Since observed segregation $\left(D_{m t}\right)$ has an expected and a systematic component, simply comparing observed segregation before and after the abolition of SCAs does clearly not yield the possible effect of the abolition of catchment areas on segregation. Therefore, we analyze changes in observed, expected, and systematic segregation. The index of systematic segregation is given by

$$
\hat{D}_{m t}=D_{m t}-\bar{D}_{m t}^{*}
$$

where $\hat{D}_{m t}$ is the extent to which the allocation of students is dissimilar compared to a purely random enrollment. ${ }^{9}$ When computing (2), $\bar{D}_{m t}^{*}$ is the average level of expected

8 In contrast, Allen, Burgess and Windmeijer (2009) propose a bias-corrected dissimilarity measure to account for small group sizes and small proportions of minorities by calculating bootstrap versions of $D_{m t}$. To generate the bootstrap sample, they randomly allocate individuals to units, holding the number of individuals and the proportions of individuals constant. Consequently, the unit size - in our example, the school size - may vary.

9 One drawback of the Carrington and Troske (1997) approach is that it might overcorrect the true level of segregation; hence, the level of systematic segregation might be underestimated. As shown in Rathelot (2011) the Theil index $H$ is less sensitive to the correction than $D$. Therefore, we have calculated both, the systematic $D$ and the systematic $H$, and compared both estimation results (see 
segregation from 100 repetitions of a random allocation of students. After subtracting the average expected level of segregation $\bar{D}_{m t}^{*}$ from the observed level of segregation, $D_{m t}$, the systematic component, $\hat{D}_{m t}$, measures segregation caused by residential and school choice. Hence, even in the absence of school choice or SCAs, systematic segregation exists as long as there is residential segregation. As mentioned above, in this study we assume that abolishing binding SCAs does not affect residential segregation in a substantial manner in the short run; thus, an increase in the index of systematic segregation $\hat{D}_{m t}$ after abolishing SCAs can be interpreted as the result of adjustments in school choice behavior.

Furthermore, our analysis also accounts for heterogeneity within NRW. The level of segregation and the adjustment in segregation might not be uniform across municipalities in NRW. Urban areas that are characterized by ethnic diversity and socio-economic disparities compared to rural areas that are more homogeneous with respect to ethnicity and socio-economic conditions. Hence, we employ an estimation approach to explain differences in systematic segregation before and after the school year 2008/09.

\subsection{Estimation strategy}

The basic model to explain systematic segregation is a fixed effect model

$$
\hat{D}_{m t}=\mathbf{x}_{m t}^{\prime} \beta+\gamma S C A_{m t}+u_{m}+\varepsilon_{m t},
$$

where the dependent variable $\hat{D}_{m t}$ is the index of systematic segregation and $\mathbf{x}_{m t}^{\prime}$ is a set of control variables. $S C A_{m t}$ is the dummy variable for school catchment areas. It has a value of 1 if school catchment areas exist and 0 otherwise. $u_{m}$ represents the municipality fixed effect and $\varepsilon_{m t}$ is the i.i.d. error term. As noted above, only 15 of the 396 municipalities abolished catchment areas in 2007/08, while the vast majority of municipalities waited until 2008/09; hence there is only little variation in the dummy of SCA. Furthermore, to control for time effects, we include time dummies in our estimation equation. Since the year dummies and the SCA dummy are almost linearly dependent, including the catchment area dummy and time dummies over-specifies the model and biases the estimated trend in systematic segregation and/or the effect of

Appendix, Table A.1). It turns out that changes in the indices of systematic segregation, in particular the differences between two points in time, are very similar. Hence, we report only results for $D$ here, as these results have a more intuitive interpretation. 
abolishing SCAs. Therefore, we exclude the small group of 15 municipalities which abolished SCAs in 2007/08 and include year dummies in the regression.

As we are particularly interested in the effect of the abolishment of SCAs and not in explaining the levels of segregation, we estimate the model in first differences. This removes the municipality fixed effect $u_{m}$ and the deterministic trend in the dependent and independent variables. Hence we estimate

$$
\Delta \hat{D}_{m t}=\Delta \mathbf{x}_{m t}^{\prime} \beta+\mathbf{T}_{t}^{\prime} \delta+\Delta \varepsilon_{m t}
$$

In (4) $\mathbf{T}_{t}^{\prime}$ includes year dummies for 2004 to 2010, with the first year 2003 being lost due to first differencing the data and $\Delta \mathbf{x}_{m t}^{\prime}$ includes the first differences of a set of explanatory variables. If the rise in systematic segregation is in fact increasing since 2008, the coefficients for the year dummies for 2004 to 2007 (years with SCAs) should be significantly lower compared to 2008, 2009, and 2010, the years without SCAs. Equation (4) is estimated using OLS and we use block bootstrap to compute standard errors (Bertrand, Duflo, and Mullainathan, 2004). Using 2008 as the reference year, the year dummies for the years 2004 to 2007 are expected to have negative coefficients. The coefficients for the later years, however, should be greater or equal to zero. In addition, to check the robustness of our results, we estimate a simple before/after model in which we reduce the time dimension of our model to the average of the years before and after the policy change. ${ }^{10}$

\section{Results}

\subsection{Measures of segregation}

Figure 1 (a) illustrates the average observed, expected, and systematic segregation of Turkish and German students in NRW. Figure 1 (b) shows the segregation between Muslim and non-Muslim students. All figures include only municipalities that have abolished their SCAs in 2008/09. And note that municipalities with only one school or no minority students as well as municipalities with less than five schools (the NRW median in 2003/04) and with fewer than the median number of minority students (the median number of Turkish students is seven) are excluded from the analysis. We exclude those municipalities, because segregation can (technically) not be avoided in

10 As suggested by Bertrand, Duflo, and Mullainathan (2004). 
small municipalities with only few minority students, regardless of the distribution of minority students. ${ }^{11}$

The upper panels, (a1) and (b1), show the average observed and the average expected level of segregation. The grey area marks the interval between the minimum and maximum computed level of expected segregation. ${ }^{12}$ The lower panels ((a2) and (b2)) are respective plots of observed and systematic segregation.

As it turns out, segregation between Turkish and German students (Figure (a)) is generally higher as compared to segregation between Muslim and non-Muslim students (Figure (b)), regardless of the measure of segregation. Moreover, Figure (a1) shows a common positive trend in observed segregation for Turkish students as opposed to German students (cf. black diamonds). As the circles indicate, the NRW-wide average level of observed segregation has been significantly increasing since 2006/07. Only the increase from 2007/08 to 2008/09 is not significant. Different from the trend in segregation between Turkish and German students, observed segregation between Muslim and non-Muslim students remains fairly unchanged during the entire time period (Figure (b1), black diamonds).

One potential problem in our descriptive analysis is the role of residential segregation. As noted earlier, the data do not allow computing a measure of residential segregation. Hence, it cannot be ruled out that higher observed segregation between Turkish and German students is eventually caused by rising residential segregation. However, in Section 4.1 we argued, why residential segregation might be disregarded in this context; because it is unlikely that residential segregation changes in such a short period of time.

While residential segregation might not be a problem in the analysis, observed segregation is clearly affected by group size and the minority proportion (cf. Section 4.2). Whenever the minority proportion decreases, observed segregation - and this is a well-known weakness of the dissimilarity indices - automatically increases. Hence, the index of systematic segregation, $\hat{D}_{m t}$, is the more appropriate measure to analyze changes in segregation. After controlling for varying group sizes, i.e. after subtracting the level of expected segregation $\bar{D}_{m t}^{*}$, we only observe a very moderate increase in

11 Consider a municipality with two minority students, 100 non-minority students and three schools. In this example, segregation can simply not be avoided, regardless of how the minority students are allocated.

12 The minimum and the maximum are the NRW-wide means of the lowest and highest values from the 100 repetitions of calculating expected segregation. 
systematic segregation for the group of Turkish students since 2007/08 (cf. Figure 1, panel (a2), black triangles). Actually, most of the changes in observed segregation $D_{m t}$ are explained by changes in expected segregation and are therefore driven by varying group sizes and varying minority proportions. We interpret this finding as support of our assumption of constant residential segregation. Changes in residential segregation are not reflected in expected segregation. Hence, a common trend in observed and expected segregation does not coincide with changes in residential segregation.

The only significant change in systematic segregation between Turkish and German students occurs in 2007/08. But, since SCAs still exist in 2007/08, the significant increase in systematic segregation cannot be attributed to the abolition of school catchment areas. One possible explanation is the amendment of the nationality law. Since all children from long term foreign residents born after 2000 are German citizens, the number of non-German students declines. The first school year, in which an entire cohort is affected by the amendment, is 2007/08. The drop in the number of non-German students is captured in the measure of expected segregation. However, not only do we observe a decline in the number of non-German students, we also expect the composition of the group of non-German students (here the group of Turkish students) to change. Children from better integrated long-term residents of Turkish descent are no longer included in the group of Turkish students. This composition effect is not captured by expected segregation but is still reflected in our measure of systematic segregation.

Other than the described trend of increasing segregation for the group of Turkish students, observed segregation between Muslim and non-Muslim students in Figure (b) is constant over time; systematic segregation has even decreased slightly since 2006/07. Hence, while systematic segregation is not constant for all minority groups, there appears to be no common trend, and changes in systematic segregation appear to be unrelated to the abolition of school catchment areas.

\subsection{Regression analysis}

In the final step of the analysis, we estimate regression models to explain changes in systematic segregation in our sample of NRW municipalities as discussed in Section 4.3. The control variables used in the regressions are described in Table 2. 
To explain systematic segregation in primary schools on the municipality level, information on the municipalities and the heterogeneity within a municipality is needed. As the level of segregation is aggregated at the municipality level, it is not straightforward to find appropriate explanatory variables that meet the criteria of good controls. Municipality characteristics like population density, income, unemployment rate and share of migrants might explain heterogeneity between municipalities but not within a municipality. In addition, within a time period of eight years there is only little variation within each municipality. Hence, we construct a set of auxiliary variables that meet the key requirement for good controls: the variable must not be an outcome of the treatment. For example, we include a dummy variable which equals 1 if the municipality has no denominational schools and 0 otherwise. Having denominational schools is a long tradition in the NRW school system, hence this variable is predetermined and not an outcome of the abolishment of SCAs. We expect systematic segregation for Turkish as well as for Muslim students to be higher in municipalities with denominational schools, as such schools might be less often chosen by minority groups (Kristen, 2005) and are an alternative to public primary schools even with binding SCAs. We also control for the share of minority students in each municipality. Systematic school segregation is expected to be higher in municipalities with a high minority share, where the population is more likely to be segregated in general. Moreover, we expect a composition effect resulting from the new nationality law as discussed in Section 3 that will ceteris paribus lead to higher levels of systematic segregation.

Since school choice can only be executed if there are alternatives, a school competition variable is generated. For each primary school and each school year, we use the number of neighboring schools within a radius of $2 \mathrm{~km}$ around the school (Euclidian distance) and calculate the average number of neighboring schools in the municipality. A value of 3, for instance, indicates that each primary school in the municipality has to compete with three other primary schools on average. In the sample without the small municipalities used here, the mean competition is 2.52 in 2006/07 for the group of Turkish students and 2.22 for the group of Muslim students (Table 2), respectively.

To control for ethnic and school heterogeneity within a municipality, we calculate the coefficients of variation for the minority students and the transfer rate to 
the academic track ${ }^{13}$. Unlike in other countries, Germany does not provide information on school quality in terms of performance measures, neither at the school level nor at the individual level. Hence, we use the transfer rates to the academic track, which are available at the school level, as a proxy of school quality. Note that the transfer rate is predetermined because it measures educational success of fourth graders, who are about to transfer to secondary school and in our sample fourth graders are not affected by the abolition of SCAs. Our measure of ethnic heterogeneity is constructed as follows: we take the share of minority students at the schools within a radius of $2 \mathrm{~km}$ (again the competition radius), including only information on the neighboring schools and excluding the school itself. We use this information, calculate the coefficient of variation $^{14}$ and transform it into a rank order of municipalities. The advantage of using the rank order instead of using the original measure of heterogeneity is that the rank order is not an outcome of abolishing SCAs. It is a variable measuring only the relative extend of heterogeneity.

In the first estimation approach the dependent variable is the first difference in systematic segregation $\Delta \hat{D}_{m t}=\hat{D}_{m t}-\hat{D}_{m, t-1}$. In the following we report the results for the group of Turkish vs. German students (Table 3) and Muslim vs. non-Muslim students (Table 4). Models (1) to (4) report the first-difference estimation results. The standard errors are group (municipality) bootstrapped. Model (5) uses average before/after values only.

The dependent variable in Table 3 in columns (1) to (4) is the first difference in systematic segregation $\Delta \hat{D}_{m t}$ between Turkish and German students. In model (1) only the year dummies are included. The year 2008, the year in which binding catchment areas were abolished, is the base category. The coefficients for 2004 to 2006 are not significantly different from 2008. Only the coefficient for 2007 is positive and significant, hence supporting the descriptive results of Figure 1 that systematic

13 After primary school, German students get a (more or less binding) teacher recommendation for a secondary school. In NRW, the alternatives are a basic track school, an intermediate track school, an academic track school, and a comprehensive school, which has an internal tracking system. The most prestigious of these tracks is the academic track school. After graduation from an academic track school (Abitur), academic track students are entitled to study at university. Hence, following Schneider et al. (2012), we use transfer rates as a measure of school quality.

14 We use the coefficient of variation and not the average minority share or the standard deviation to capture heterogeneity. The standard deviation does not reflect heterogeneity appropriately; municipalities with a high minority share have a higher standard deviation but are not necessarily more heterogeneous than municipalities with lower minority shares. Moreover, the average minority proportion is also clearly an inappropriate measure as it yields no information about the distribution of minorities within the municipality. 
segregation rose in 2007/08, the year before SCAs have been abolished. An explanation, proposed in Section 3, is the change in the nationality law and its effect on the composition of first graders. In 2009, growth in segregation is again significantly higher than in 2008 and in 2010 there is no significant increase. In Model (2) we include the share of Turkish students and the log number of first graders to control for the population size and its composition. As expected, systematic segregation is higher in municipalities with a large number of first graders and significantly higher with a high minority share. As high minority shares characterize municipalities with a high socioeconomic diversity, higher systematic segregation is plausible. The size of the municipality, measured by the number of first graders, turns out to be significant at the 10\%-level. But note that the dummy for 2009 ceases to be significant. In Model (3) we include controls characterizing primary schools like the dummy for denominational schools, the school competition variable and school heterogeneity. The share of Turkish students and the number of first graders remain significant. Besides that, only the denominational schools dummy has a significant and negative effect on segregation. As expected, municipalities without denominational schools are significantly less segregated than municipalities with both public and denominational schools. Model (4) controls for ethnic diversity. The coefficient is, as expected, significant and positive. The higher the relative ethnic diversity in the municipalities, the higher the level of systematic segregation.

The results of the robustness check in the before/after-model, reported in Model (5) (Table 3) are quite similar to the results of the first-difference estimation in Model (4) and the SCA dummy is not significant. Thus, the growth in systematic segregation between Turkish and German students is uncorrelated with the existence of SCAs.

Table 4 summarizes the results for systematic segregation of Muslim and nonMuslim students. Generally, the results are consistent with the results for Turkish versus German students, though there are some differences. For the group of Muslim students we observe a higher increase in systematic segregation in 2006 compared to 2008, but there is no significant increase in systematic segregation after the abolishment of SCAs (Table 4). This is in line with the results for Turkish students. The share of Muslim students has the expected positive and significant effect on segregation and so does the number of first graders in each of our first difference specifications. Larger municipalities with a higher share of Muslim students have higher levels of segregation. Again, in the before/after estimation the SCA dummy is not significant (Model (5)). In 
comparison to the results for Turkish vs. German students (Table 3) the denominational school dummy is not significant and the effect of the number of first graders disappears in Model (5). In addition, the school competition variable is significant indicating that systematic segregation increases with more school competition in a municipality.

Summarizing the results, we state that the differences in systematic segregation are largely determined by characteristics of the municipalities and school characteristics. The abolition of school catchment areas appears to have no effect on systematic segregation. Hence, it is not clear at all whether a reintroduction of SCAs will in fact solve the problem of ethnic primary school segregation within a municipality and lead to more equality in education.

\section{Conclusion}

North Rhine-Westphalia, the most populous German federal state, abolished primary school catchment areas in 2008. Critics argued that ethnic school segregation might increase if parents are allowed to freely choose a primary school. Given that socioeconomic and ethnic background already explain academic achievement in Germany to a larger extent than in other countries, an increase in school segregation by ethnicity is not desirable. However, little is known about primary school choice in Germany in general and its effect on ethnic school segregation in particular.

In this paper, we use administrative data from the school years 2006/07 to 2010/11 on primary schools in all municipalities in NRW to analyze changes in ethnic segregation over time. The well-known drawbacks of the commonly-used segregation indices in samples with small minority shares have been addressed in the literature, and methods to compare dissimilarity indices have been discussed.

We contribute to the literature on school choice and segregation by using a segregation index that is corrected for expected segregation resulting from a random allocation of students, and we analyze systematic segregation of Turkish and German students and Muslim and non-Muslim students. Furthermore we discuss drawbacks of these indices and the administrative data used in this study. We proceed in two steps. First we present some descriptive analyses to show differences of observed, expected and systematic segregation and their variation over time. Second, we explain changes in systematic segregation in a regression model to better account for the heterogeneity of municipalities in NRW. While there are some changes in ethnic systematic segregation 
during our sample period, we cannot attribute these changes to the existence or absence of school catchment areas (SCAs). In fact, SCAs appear not to matter for primary school segregation in NRW. However, municipality controls like the ethnic student composition, the degree of school competition or available alternatives, and the heterogeneity within a municipality explain the variation in segregation fairly well.

The NRW government allowed municipalities to reintroduce SCAs for the school year 2011/12 or later. So far, municipalities have hesitated to exercise that option and our results provide an explanation for this reluctance: catchment areas do not reduce or enhance ethnic school segregation in NRW.

While our analysis can answer some questions, there are still some unresolved issues. For instance, with the data at hand we are not able to estimate the level of residential segregation and at this stage we hesitate to give a causal interpretation to our results. Furthermore, there is no data on school performance available in NRW; hence, an effect of ethnic segregation of Turkish and German students on outcomes, such as achievement levels and learning opportunities, cannot be analyzed at all. Finally, our data only comprise the first three years after SCAs were abolished. It might take more time for parents to learn how to practice school choice.

\section{References}

Allen, R., Burgess, S., Windmeijer, F. (2009): More reliable inference for segregation indices. CMPO Working Papers, No. 09/216.

Altrichter, H., Bacher, J., Beham, M., Nagy, G., Wetzelhütter, D. (2011): The effects of a free school choice policy on parents' school choice behaviour. Studies in Educational Evaluation 37, 230-238.

Aslund, O. and Skans, O. N. (2009): How to measure segregation conditional on the distribution of covariates. Journal of Population Economics 22, 971-981.

Bertrand, M., Duflo, E., Mullainathan, S. (2004): How much should we trust differences-in-differences estimates? The Quarterly Journal of Economics 119, 249-275.

Bifulco, R., Ladd, H. F., Ross, S. L. (2009): Public school choice and integration evidence from Durham, North Carolina. Social Science Research 38, 71-85.

Burgess, S., Briggs, A. (2006): School assignment, school choice and social mobility. CMPO Working Papers, No. 06/157.

Carrington, W., Troske, K. (1997): On measuring segregation in samples with small units. Journal of Business and Economic Statistics 15, 402-409.

Cortese, C., Falk, R., Cohen, J. (1976): Further considerations on the methodological analysis of segregation indices. American Sociological Review 41, 630-637. 
Duncan, O., Duncan, B. (1955): A methodological analysis of segregation indexes. American Sociological Review 20, 210-217.

Dustmann, C. (2004): Parental background, secondary school track choice, and wages. Oxford Economic Papers 56, 209-230.

Dustmann, C., Glitz, A., and Schönberg, U. (2009): Job search networks and ethnic segregation in the workplace. University College London, Working Paper.

Federal Office for Migration and Refugees (2009): Muslimisches Leben in Deutschland [Muslim life in Germany], Forschungsbericht 6. url: http://www.bamf.de/SharedDocs/Anlagen/DE/Publikationen/Forschungsberichte/fb 6-muslimisches-leben.html [2011, September 20]

Figlio, D. N., Hart, C. M. D. (2010): Competitive effects of means-tested school vouchers. NBER Working Papers. No. 16056.

Fryer, R. G., Levitt, S. D. (2004): Understanding the black-white test score gap in the first two years of school. Review of Economics and Statistics 86, 447-464.

Hanushek, E. A., Kain, J. F., Rivkin, S. G. (2009): New evidence about brown v. board of education: The complex effects of school racial composition on achievement. Journal of Labor Economics 27, 349-383.

Hastings, J. S., Weinstein, J. M. (2008): Information, school choice, and academic achievement: Evidence from two experiments. The Quarterly Journal of Economics 123, 1373-1414.

Hoxby, C. (2003): School choice and School productivity: Could school choice be a tide that lifts all boats? In: C. Hoxby (Ed.). The economics of school choice. University of Chicago Press, Chicago, 287-342.

Kristen, C. (2005): School choice and ethnic school segregation: Primary school selection in Germany. Waxmann, Münster.

Lankford, H., Wyckoff, J. (2001): Who would be left behind by enhanced private school choice? Journal of Urban Economics 50, 288-312.

O’Shaughnessy, T. (2007): Parental choice and school quality when peer and scale effects matter. Economics of Education Review 26, 501-515.

Rathelot, R. (2011): Measuring segregation when units are small: A parametric approach. CREST - Série des Documents de Travail, No. 2011-06.

Riedel, A., Schneider, K., Schuchart, C., Weishaupt, H. (2010): School choice in German primary schools: How binding are school districts? Journal for Educational Research Online 2, 94-120.

Schneider, K., Schuchart, C., Weishaupt, H., Riedel, A. (2012): The effect of primary school choice on ethnic groups - evidence from a policy reform. In: European Journal of Political Economy 28, 430-444.

Söderström, M., Uusitalo, R. (2010): School choice and segregation: Evidence from an admission reform. The Scandinavian Journal of Economics 112, 55-76.

Statistisches Bundesamt (2010): Bevölkerung mit Migrationshintergrund - Ergebnisse des Mikrozensus 2009 [Citizens with a migration background - results from the Mikrozensus 2009], Fachserie 1, Reihe 2.2.

Wößmann, L. (2008): Efficiency and equity of European education and training policies. International Tax and Public Finance 15, 199-230. 
Figure 1 Average observed, expected, and systematic segregation in NRW, 2003/04 to 2010/11

(a) Turkish vs. German students

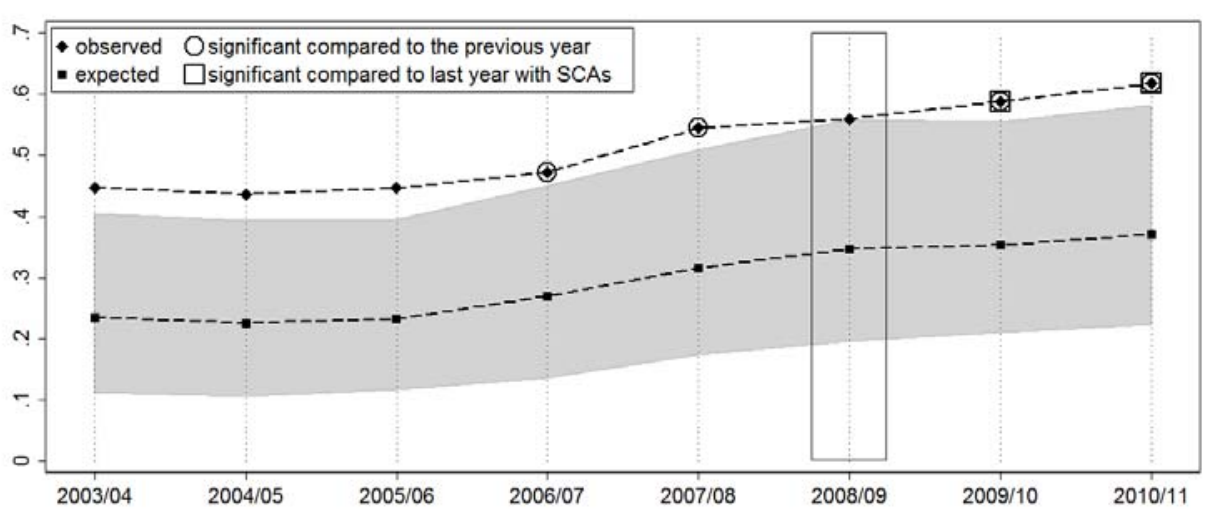

(a1) Observed and expected segregation

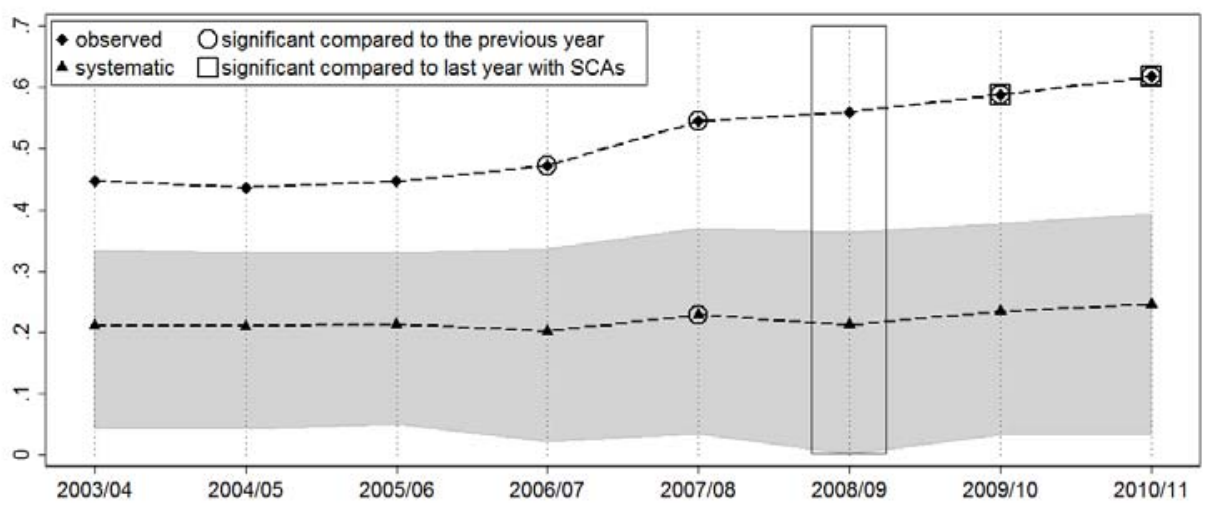

(a2) Observed and systematic segregation (b) Muslim vs. non-Muslim students

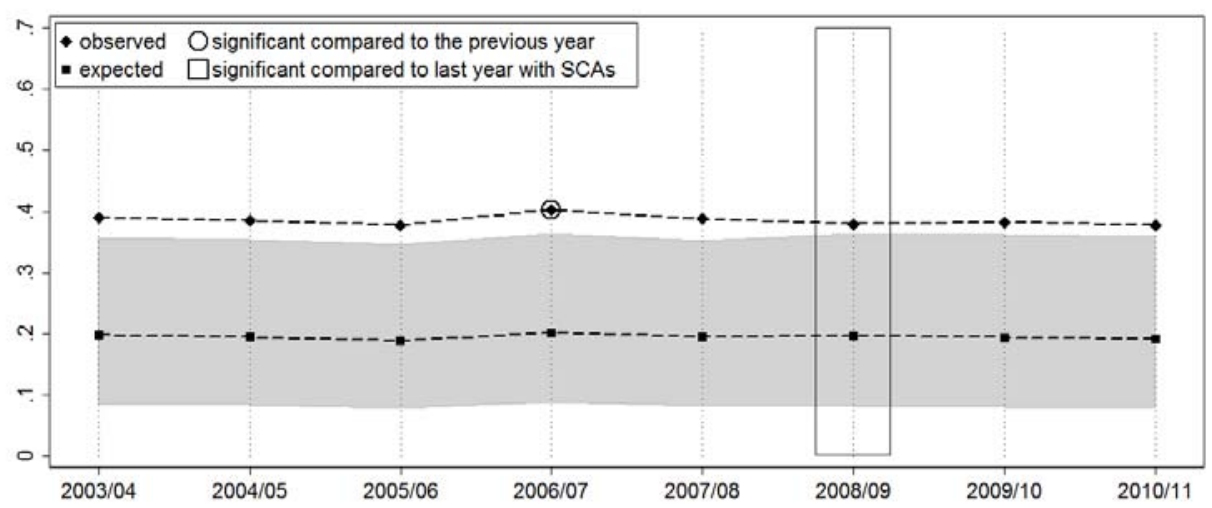

(b1) Observed and expected segregation

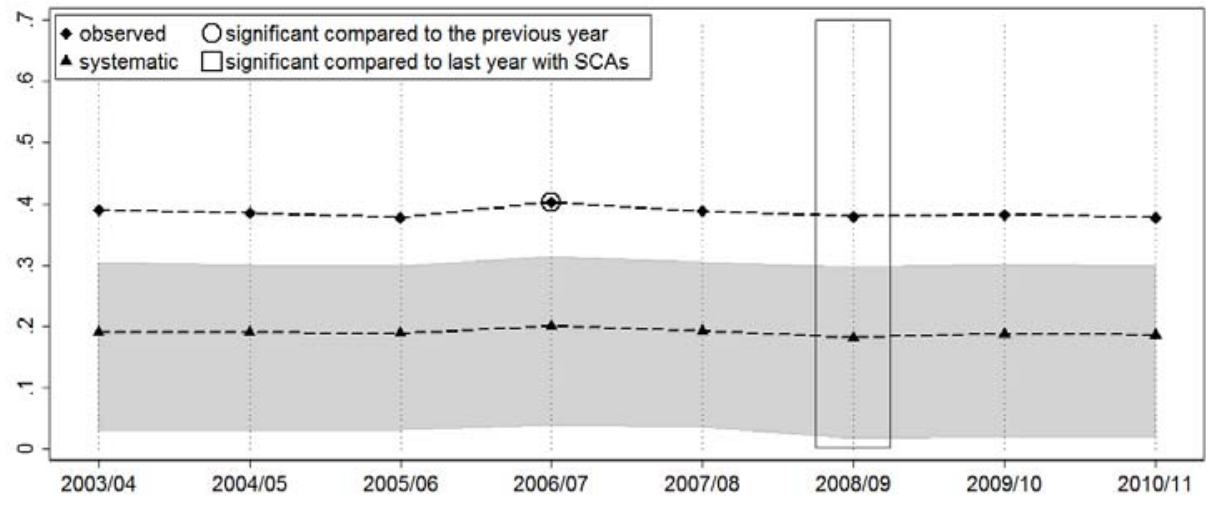

(b2) Observed and systematic segregation

Notes: The year of abolishment is highlighted by a black border. Expected segregation is calculated as the average segregation index obtained from a repeated random allocation of students to

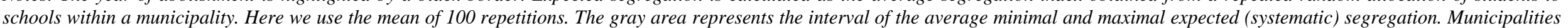
which have abolished SCAs in 2007/08 are excluded. Municipalities below the median level of schools and minority students and municipalities with one school or no minority students are excluded. Significance level of the t-test (mean comparison test for $H_{0}: \widehat{D}_{m, t+1}-\widehat{D}_{m t}=0\left(D_{m, t+1}-D_{m t}=0\right)$ ) is 0.05 . 


\begin{tabular}{lrrrrrrrr}
\hline & & \multicolumn{7}{c}{ Number of schools ${ }^{a)}$} \\
\hline School year ${ }^{b)}$ & $2003 / 04$ & $2004 / 05$ & $2005 / 06$ & $2006 / 07$ & $2007 / 08$ & $2008 / 09$ & $2009 / 10$ & $2010 / 11$ \\
\hline All primary schools & 3,415 & 3,414 & 3,408 & 3,400 & 3,355 & 3,249 & 3,195 & 3,144 \\
$\quad$ public schools & 2,194 & 2,192 & 2,189 & 2,185 & 2,161 & 2,104 & 2,082 & 2,048 \\
$\quad$ catholic schools & 1,101 & 1,101 & 1,097 & 1,093 & 1,070 & 1,023 & 987 & 968 \\
$\quad$ protestant schools & 94 & 94 & 94 & 93 & 91 & 84 & 82 & 82 \\
\hline & & & & & & & & \\
\hline School year & & & & Students in $1^{\text {st }}$ grade & & & \\
\hline Students in primary schools ${ }^{c)}$ & 191,112 & 187,452 & 184,280 & 174,310 & 175,615 & 161,783 & 164,873 & 153,101 \\
German & 162,556 & 158,409 & 155,281 & 150,599 & 154,690 & 143,755 & 146,818 & 136,382 \\
non-German ${ }^{\text {d) }}$ & 28,556 & 29,043 & 28,999 & 23,711 & 20,925 & 18,028 & 18,055 & 16,719 \\
Turkish & 15,117 & 15,455 & 15,308 & 11,457 & 9,509 & 7,448 & 7,154 & 6,256 \\
Muslim & 24,318 & 25,490 & 26,179 & 24,758 & 25,907 & 23,967 & 25,052 & 24,168 \\
non-Muslim & 166,794 & 161,962 & 158,101 & 149,552 & 149,708 & 137,816 & 139,821 & 128,933 \\
\hline \% non-German & 14.9 & 15.5 & 15.7 & 13.6 & 11.9 & 11.1 & 11.0 & 10.9 \\
\% Turkish & 7.9 & 8.2 & 8.3 & 6.6 & 5.4 & 4.6 & 4.3 & 4.1 \\
\% Muslim & 12.7 & 13.6 & 14.2 & 14.2 & 14.8 & 14.8 & 15.2 & 15.8 \\
\hline \hline
\end{tabular}

Notes: ${ }^{a)}$ Only schools with a $1^{\text {st }}$ grade are included. ${ }^{b)}$ The $4^{\text {th }}, 3^{\text {rd }}$, and $2^{\text {nd }}$ grades of the 2006/07 school year are used as an estimate of first grades in 2003/04, 2004/05, and 2005/06. ${ }^{c}$ Students in private primary schools are excluded. ${ }^{d)}$ Including ethnic German immigrants ("Aussiedler"). 
Table 2 Description of the variables, means, first differences, and before/after differences

\begin{tabular}{|c|c|c|c|c|c|c|}
\hline & $\begin{array}{c}\text { Systematic } \\
\text { segre- } \\
\text { gation }\end{array}$ & $\begin{array}{l}\text { share of } \\
\text { minority } \\
\text { students }\end{array}$ & $\begin{array}{c}\text { First } \\
\text { graders }\end{array}$ & $\begin{array}{c}\text { School } \\
\text { compe- } \\
\text { tition }\end{array}$ & $\begin{array}{l}\text { School } \\
\text { hetero- } \\
\text { geneity }^{\text {b) }}\end{array}$ & $\begin{array}{l}\text { Ethnic } \\
\text { hetero- } \\
\text { geneity }^{\text {a) }}\end{array}$ \\
\hline \multicolumn{7}{|c|}{ Turkish vs. German students (185 municipalities) - means } \\
\hline 2003 & 0.211 & 0.081 & 765.1 & 2.546 & 0.311 & 0.548 \\
\hline 2004 & 0.210 & 0.088 & 749.3 & 2.544 & 0.311 & 0.551 \\
\hline 2005 & 0.214 & 0.088 & 736.6 & 2.535 & 0.311 & 0.555 \\
\hline 2006 & 0.202 & 0.068 & 699.4 & 2.517 & 0.302 & 0.619 \\
\hline 2007 & 0.229 & 0.055 & 705.7 & 2.499 & 0.304 & 0.752 \\
\hline 2008 & 0.213 & 0.047 & 651.8 & 2.437 & 0.310 & 0.784 \\
\hline 2009 & 0.235 & 0.047 & 663.8 & 2.384 & 0.293 & 0.797 \\
\hline 2010 & 0.246 & 0.043 & 621.1 & 2.319 & 0.307 & 0.809 \\
\hline
\end{tabular}

Turkish vs. German students (185 municipalities) - first differences

2003

\begin{tabular}{|c|c|c|c|c|c|c|}
\hline 2004 & -0.001 & 0.007 & -15.784 & -0.003 & 0.000 & 0.003 \\
\hline 2005 & 0.003 & 0.000 & -12.681 & -0.009 & 0.000 & 0.004 \\
\hline 2006 & -0.011 & -0.020 & -37.238 & -0.017 & -0.009 & 0.064 \\
\hline 2007 & 0.026 & -0.013 & 6.357 & -0.019 & 0.003 & 0.133 \\
\hline 2008 & -0.016 & -0.007 & -53.886 & -0.062 & 0.005 & 0.032 \\
\hline 2009 & 0.022 & 0.000 & 12.049 & -0.052 & -0.017 & 0.013 \\
\hline 2010 & 0.011 & -0.005 & -42.757 & -0.065 & 0.014 & 0.011 \\
\hline
\end{tabular}

Turkish vs. German students (185 municipalities) - mean first differences

\begin{tabular}{|c|c|c|c|c|c|c|}
\hline before (2003 - 2007) & 0.004 & -0.007 & -14.836 & -0.012 & -0.002 & 0.051 \\
\hline after $(2008-2010)$ & 0.006 & -0.004 & -28.198 & -0.060 & 0.001 & 0.019 \\
\hline \multicolumn{7}{|c|}{ Muslim vs. non-Muslim students (228 municipalities) - means } \\
\hline 2003 & 0.191 & 0.100 & 675.658 & 2.250 & 0.295 & 0.461 \\
\hline 2004 & 0.190 & 0.109 & 662.083 & 2.248 & 0.295 & 0.489 \\
\hline 2005 & 0.189 & 0.113 & 650.509 & 2.237 & 0.295 & 0.443 \\
\hline 2006 & 0.201 & 0.110 & 616.307 & 2.223 & 0.295 & 0.491 \\
\hline 2007 & 0.192 & 0.113 & 621.741 & 2.204 & 0.297 & 0.493 \\
\hline 2008 & 0.182 & 0.115 & 574.140 & 2.144 & 0.299 & 0.478 \\
\hline 2009 & 0.188 & 0.119 & 584.110 & 2.096 & 0.284 & 0.447 \\
\hline 2010 & 0.186 & 0.123 & 545.868 & 2.039 & 0.300 & 0.466 \\
\hline
\end{tabular}

Muslim vs. non-Muslim students (228 municipalities) - first differences 2003

\begin{tabular}{lrrrrrr}
2004 & -0.001 & 0.009 & -13.575 & -0.002 & 0.000 & 0.028 \\
2005 & -0.001 & 0.004 & -11.575 & -0.011 & -0.000 & -0.046 \\
2006 & 0.012 & -0.003 & -34.202 & -0.014 & -0.000 & 0.048 \\
2007 & -0.008 & 0.003 & 5.434 & -0.019 & 0.002 & 0.001 \\
2008 & -0.010 & 0.001 & -47.601 & -0.059 & 0.002 & -0.015 \\
2009 & 0.006 & 0.005 & 9.969 & -0.048 & -0.015 & -0.031 \\
2010 & -0.002 & 0.004 & -38.241 & -0.057 & 0.016 & 0.019 \\
\hline \multicolumn{7}{l}{ Muslim vs. non-Muslim students (228 municipalities) - mean first differences } \\
before (2003 - 2007) & 0.000 & 0.003 & -13.479 & -0.012 & 0.000 & 0.008 \\
after (2008 - 2010) & -0.002 & 0.003 & -25.291 & -0.055 & 0.001 & -0.009 \\
\hline \hline
\end{tabular}

Notes: ${ }^{a)}$ Ethnic heterogeneity is the coefficient of variation for the minority students at the schools within a $2 \mathrm{~km}$ radius. ${ }^{b)}$ School heterogeneity is the coefficient of variation for the transfer rate to the academic track. Municipalities which have abolished SCAs in 2007/08 are excluded. Municipalities below the median level of schools and minority students and municipalities with one school or no minority students are excluded. 
Table 3 Cross section model for systematic segregation, Turkish vs. German students

\begin{tabular}{|c|c|c|c|c|c|}
\hline & \multicolumn{4}{|c|}{ First differences } & \multirow{2}{*}{$\begin{array}{c}\text { Before/After } \\
\text { (5) }\end{array}$} \\
\hline & (1) & $(2)$ & (3) & (4) & \\
\hline Year $=2004$ & $\begin{array}{c}0.0149 \\
(0.0152)\end{array}$ & $\begin{array}{l}-0.0094 \\
(0.0160)\end{array}$ & $\begin{array}{l}-0.0105 \\
(0.0167)\end{array}$ & $\begin{array}{l}-0.0129 \\
(0.0149)\end{array}$ & \\
\hline Year $=2005$ & $\begin{array}{c}0.0192 \\
(0.0121)\end{array}$ & $\begin{array}{c}0.0014 \\
(0.0124)\end{array}$ & $\begin{array}{c}0.0003 \\
(0.0125)\end{array}$ & $\begin{array}{l}-0.0007 \\
(0.0121)\end{array}$ & \\
\hline Year $=2006$ & $\begin{array}{c}0.0046 \\
(0.0149)\end{array}$ & $\begin{array}{c}0.0165 \\
(0.0152)\end{array}$ & $\begin{array}{c}0.0156 \\
(0.0155)\end{array}$ & $\begin{array}{c}0.0188 \\
(0.0141)\end{array}$ & \\
\hline Year $=2007$ & $\begin{array}{l}0.0423^{* *} \\
(0.0176)\end{array}$ & $\begin{array}{l}0.0369^{* *} \\
(0.0180)\end{array}$ & $\begin{array}{l}0.0380^{* *} \\
(0.0185)\end{array}$ & $\begin{array}{l}0.0393^{* *} \\
(0.0178)\end{array}$ & \\
\hline \multicolumn{6}{|l|}{ Year = 2008 (base) } \\
\hline Year $=2009$ & $\begin{array}{l}0.0379^{* *} \\
(0.0187)\end{array}$ & $\begin{array}{c}0.0155 \\
(0.0200)\end{array}$ & $\begin{array}{c}0.0164 \\
(0.0199)\end{array}$ & $\begin{array}{c}0.0152 \\
(0.0184)\end{array}$ & \\
\hline Year $=2010$ & $\begin{array}{c}0.0274 \\
(0.0187)\end{array}$ & $\begin{array}{c}0.0242 \\
(0.0178)\end{array}$ & $\begin{array}{c}0.0236 \\
(0.0177)\end{array}$ & $\begin{array}{c}0.0230 \\
(0.0165)\end{array}$ & \\
\hline $\begin{array}{l}\text { Share of Turkish students } \\
\text { in municipality }\end{array}$ & & $\begin{array}{l}1.1841^{* * *} \\
(0.2463)\end{array}$ & $\begin{array}{l}1.1612^{* * *} \\
(0.2479)\end{array}$ & $\begin{array}{l}1.3747^{* * *} \\
(0.2374)\end{array}$ & $\begin{array}{l}2.1360^{* * *} \\
(0.3197)\end{array}$ \\
\hline $\begin{array}{l}\log \text { (Number of first graders } \\
\text { in municipality) }\end{array}$ & & $\begin{array}{l}0.1284^{+} \\
(0.0660)\end{array}$ & $\begin{array}{l}0.1250^{+} \\
(0.0667)\end{array}$ & $\begin{array}{l}0.1236^{+} \\
(0.0631)\end{array}$ & $\begin{array}{l}0.2601^{* *} \\
(0.1087)\end{array}$ \\
\hline $\begin{array}{l}\text { Denominational schools } \\
(1=\mathrm{No})\end{array}$ & & & $\begin{array}{l}-0.2228^{+} \\
(0.1159)\end{array}$ & $\begin{array}{l}-0.1812^{* *} \\
(0.0835)\end{array}$ & $\begin{array}{l}-0.0370 \\
(0.1615)\end{array}$ \\
\hline School competition & & & $\begin{array}{c}0.0134 \\
(0.0307)\end{array}$ & $\begin{array}{c}0.0078 \\
(0.0282)\end{array}$ & $\begin{array}{c}0.0393 \\
(0.0356)\end{array}$ \\
\hline School heterogeneity & & & $\begin{array}{c}0.0773 \\
(0.0520)\end{array}$ & $\begin{array}{c}0.0759 \\
(0.0469)\end{array}$ & $\begin{array}{l}-0.0366 \\
(0.0847)\end{array}$ \\
\hline $\begin{array}{l}\text { Ethnic heterogeneity } \\
\text { (Rank) }\end{array}$ & & & & $\begin{array}{l}0.0011^{* * *} \\
(0.0001)\end{array}$ & $\begin{array}{l}0.0008^{* * *} \\
(0.0003)\end{array}$ \\
\hline $\begin{array}{l}\text { School catchment areas } \\
(1=\text { Yes })\end{array}$ & & & & & $\begin{array}{l}-0.0049 \\
(0.0073)\end{array}$ \\
\hline Constant & $\begin{array}{l}-0.0159 \\
(0.0106)\end{array}$ & $\begin{array}{c}0.0040 \\
(0.0118)\end{array}$ & $\begin{array}{c}0.0052 \\
(0.0122)\end{array}$ & $\begin{array}{c}0.0061 \\
(0.0115)\end{array}$ & $\begin{array}{l}0.0304^{* * *} \\
(0.0075)\end{array}$ \\
\hline Observations & 1295 & 1295 & 1295 & 1295 & 370 \\
\hline Municipalities & 185 & 185 & 185 & 185 & 185 \\
\hline $\mathrm{R}^{2}$ & 0.011 & 0.054 & 0.065 & 0.171 & 0.177 \\
\hline Adjusted $\mathrm{R}^{2}$ & 0.006 & 0.048 & 0.057 & 0.163 & 0.161 \\
\hline
\end{tabular}


Table 4 Cross section model for systematic segregation, Muslim vs. non-Muslim students

\begin{tabular}{|c|c|c|c|c|c|}
\hline & \multicolumn{4}{|c|}{ First differences } & \multirow{2}{*}{$\begin{array}{l}\text { Before/After } \\
\text { (5) }\end{array}$} \\
\hline & $(1)$ & $(2)$ & (3) & (4) & \\
\hline Year $=2004$ & $\begin{array}{c}0.0095 \\
(0.0096)\end{array}$ & $\begin{array}{l}-0.0027 \\
(0.0105)\end{array}$ & $\begin{array}{l}-0.0048 \\
(0.0105)\end{array}$ & $\begin{array}{l}-0.0049 \\
(0.0098)\end{array}$ & \\
\hline Year $=2005$ & $\begin{array}{c}0.0088 \\
(0.0092)\end{array}$ & $\begin{array}{l}-0.0023 \\
(0.0102)\end{array}$ & $\begin{array}{l}-0.0041 \\
(0.0104)\end{array}$ & $\begin{array}{l}-0.0033 \\
(0.0088)\end{array}$ & \\
\hline Year $=2006$ & $\begin{array}{l}0.0224^{* *} \\
(0.0099)\end{array}$ & $\begin{array}{l}0.0206^{* *} \\
(0.0101)\end{array}$ & $\begin{array}{l}0.0189^{+} \\
(0.0101)\end{array}$ & $\begin{array}{l}0.0204^{* *} \\
(0.0092)\end{array}$ & \\
\hline Year $=2007$ & $\begin{array}{c}0.0018 \\
(0.0116)\end{array}$ & $\begin{array}{l}-0.0122 \\
(0.0133)\end{array}$ & $\begin{array}{l}-0.0138 \\
(0.0133)\end{array}$ & $\begin{array}{l}-0.0122 \\
(0.0117)\end{array}$ & \\
\hline \multicolumn{6}{|l|}{ Year = 2008 (base) } \\
\hline Year $=2009$ & $\begin{array}{c}0.0162 \\
(0.0127)\end{array}$ & $\begin{array}{l}-0.0000 \\
(0.0141)\end{array}$ & $\begin{array}{l}-0.0006 \\
(0.0141)\end{array}$ & $\begin{array}{l}-0.0000 \\
(0.0126)\end{array}$ & \\
\hline Year $=2010$ & $\begin{array}{c}0.0084 \\
(0.0107)\end{array}$ & $\begin{array}{c}0.0068 \\
(0.0108)\end{array}$ & $\begin{array}{c}0.0064 \\
(0.0107)\end{array}$ & $\begin{array}{c}0.0060 \\
(0.0093)\end{array}$ & \\
\hline $\begin{array}{l}\text { Share of Muslim students } \\
\text { in municipality }\end{array}$ & & $\begin{array}{l}0.4423^{* * *} \\
(0.1470)\end{array}$ & $\begin{array}{l}0.4372^{* * *} \\
(0.1482)\end{array}$ & $\begin{array}{l}0.6222^{* * *} \\
(0.1162)\end{array}$ & $\begin{array}{l}0.5589^{* *} \\
(0.2248)\end{array}$ \\
\hline $\begin{array}{l}\log \text { (Number of first graders } \\
\text { in municipality) }\end{array}$ & & $\begin{array}{l}0.1391^{* * *} \\
(0.0444)\end{array}$ & $\begin{array}{l}0.1421^{* * *} \\
(0.0450)\end{array}$ & $\begin{array}{l}0.1279^{* * *} \\
(0.0383)\end{array}$ & $\begin{array}{c}0.1032 \\
(0.0706)\end{array}$ \\
\hline $\begin{array}{l}\text { Denominational schools } \\
(1=\mathrm{No})\end{array}$ & & & $\begin{array}{l}-0.0129 \\
(0.0348)\end{array}$ & $\begin{array}{l}-0.0421 \\
(0.0491)\end{array}$ & $\begin{array}{c}0.0510 \\
(0.0758)\end{array}$ \\
\hline School competition & & & $\begin{array}{l}0.0321^{+} \\
(0.0176)\end{array}$ & $\begin{array}{c}0.0197 \\
(0.0182)\end{array}$ & $\begin{array}{l}0.0469^{* *} \\
(0.0183)\end{array}$ \\
\hline School heterogeneity & & & $\begin{array}{c}0.0086 \\
(0.0300)\end{array}$ & $\begin{array}{l}-0.0008 \\
(0.0258)\end{array}$ & $\begin{array}{c}0.0497 \\
(0.0443)\end{array}$ \\
\hline $\begin{array}{l}\text { Ethnic heterogeneity } \\
\text { (Rank) }\end{array}$ & & & & $\begin{array}{l}0.0009^{* * *} \\
(0.0001)\end{array}$ & $\begin{array}{l}0.0010^{* * *} \\
(0.0002)\end{array}$ \\
\hline $\begin{array}{l}\text { School catchment areas } \\
(1=\text { Yes })\end{array}$ & & & & & $\begin{array}{l}-0.0024 \\
(0.0042)\end{array}$ \\
\hline Constant & $\begin{array}{c}-0.0103 \\
(0.0072)\end{array}$ & $\begin{array}{c}0.0016 \\
(0.0089)\end{array}$ & $\begin{array}{c}0.0039 \\
(0.0089)\end{array}$ & $\begin{array}{c}0.0019 \\
(0.0079)\end{array}$ & $\begin{array}{c}0.0039 \\
(0.0050)\end{array}$ \\
\hline Observations & 1596 & 1596 & 1596 & 1596 & 456 \\
\hline Municipalities & 228 & 228 & 228 & 228 & 228 \\
\hline $\mathrm{R}^{2}$ & 0.004 & 0.023 & 0.025 & 0.224 & 0.267 \\
\hline Adjusted R ${ }^{2}$ & 0.001 & 0.018 & 0.018 & 0.218 & 0.255 \\
\hline
\end{tabular}

Notes: Municipalities which have abolished SCAs in 2007/08 are excluded. Municipalities below the median level of schools and minority students and municipalities with one school or no minority students are excluded. Bootstrap standard errors in parentheses, 200 replications based on 228 clusters (municipalities); ${ }^{+} p<0.10,{ }^{* *} p<0.05,{ }^{* * * *} p$ $<0.01$ 


\section{Appendix}

Table A.1 Average observed, expected, and systematic segregation in NRW, Turkish vs. German students, 2003/04 to 2010/11, measured by D and H

\begin{tabular}{|c|c|c|c|c|c|c|c|c|}
\hline Measure & $2003 / 04$ & $2004 / 05$ & 2005/06 & $2006 / 07$ & $2007 / 08$ & $2008 / 09$ & $2009 / 10$ & $2010 / 11$ \\
\hline$D_{m t}$ (observed) & 0.4469 & 0.4364 & 0.4464 & $0.4728^{a)}$ & $0.5447^{a)}$ & 0.5599 & $0.5879^{a) b)}$ & $0.6172^{a) b)}$ \\
\hline $\bar{D}_{m t}^{*}$ (expected) & 0.2354 & 0.2260 & 0.2328 & 0.2704 & 0.3160 & 0.3471 & 0.3532 & 0.3710 \\
\hline$\hat{D}_{m t}$ (systematic) & 0.2115 & 0.2104 & 0.2137 & 0.2024 & $0.2287^{a)}$ & 0.2127 & 0.2347 & 0.2462 \\
\hline$H_{m t}$ (observed) & 0.1652 & 0.1622 & 0.1646 & 0.1767 & $0.2133^{a)}$ & 0.2224 & $0.2391^{b)}$ & $0.2533^{b)}$ \\
\hline $\bar{H}_{m t}^{*}$ (expected) & 0.0515 & 0.0485 & 0.0511 & 0.0646 & 0.0808 & 0.0927 & 0.0940 & 0.1011 \\
\hline$\hat{H}_{m t}$ (systematic) & 0.1137 & 0.1137 & 0.1135 & 0.1121 & $0.1325^{a)}$ & 0.1297 & 0.1450 & 0.1522 \\
\hline
\end{tabular}

Notes: The year of abolishment is highlighted by a black border. Expected segregation is calculated as the average segregation index obtained from a repeated random allocation of students to schools within a municipality. Here, we use the mean of 100 repetitions. Municipalities which have abolished SCAs in 2007/08 are excluded. Municipalities below the median level of schools and minority students and municipalities with one school or no minority students are excluded. Significance level of the $t$-test (mean comparison test for $H_{0}: \widehat{D}_{m, t+1}-\widehat{D}_{m t}=0\left(D_{m, t+1}-\right.$ $\left.D_{m t}=0\right)$ and $\left.\widehat{H}_{m, t+1}-H_{m t}=0\left(H_{m, t+1}-H_{m t}=0\right)\right)$ is $0.05 .{ }^{a)}$ significant compared to the previous year; ${ }^{b)}$ significant compared to the last year with SCAs. 